\title{
Mass spectrometry assays of plasma biomarkers to predict radiographic progression of knee osteoarthritis
}

\author{
Susan Y Ritter ${ }^{1,2}$, Jamie Collins ${ }^{3}$, Bryan Krastins ${ }^{4}$, David Sarracino ${ }^{4}$, Mary Lopez ${ }^{4}$, Elena Losina ${ }^{2,3}$ \\ and Antonios $O$ Aliprantis ${ }^{1,2^{*}}$
}

\begin{abstract}
Introduction: Biomarkers to identify osteoarthritis $(\mathrm{OA})$ patients at risk for disease progression are needed. As part of a proteomic analysis of knee synovial fluid from normal and OA patients, differentially expressed proteins were identified that could represent potential biomarkers for OA. This study aimed to use mass spectrometry assays to identify representative peptides from several proteins in synovial fluid and peripheral blood, and assess their levels as biomarkers of OA progression.
\end{abstract}

Methods: Multiplexed high throughput selected reaction monitoring (SRM) assays were developed to measure tryptic peptides representative of 23 proteins in matched serum and synovial fluid samples from late OA subjects at the time of joint replacement. Subsequently plasma samples from the baseline visit of 173 subjects in an observational OA cohort were tested by SRM for peptides from nine of these proteins: afamin, clusterin, cartilage oligomeric matrix protein, hepatocyte growth factor, kallistatin, insulin-like growth factor binding protein, acid labile subunit, lubricin, lumican, and pigment epithelium-derived factor. Linear regression was used to determine the association between the peptide biomarker level at baseline and change in joint space width ( $\Delta J S W$ ) from baseline to 30 months, adjusting for age and sex.

Results: In the matched cohort, 17 proteins could be identified in synovial fluid and 16 proteins were detected in serum. For the progression cohort, the average age was 62 and average $\Delta$ JSW over 30 months was $0.68 \mathrm{~mm}$. A high correlation between different peptides from individual proteins was observed, indicating our assays correctly measured their target proteins. Peptides representative of clusterin, lumican and lubricin showed statistically significant associations with joint space narrowing after adjustment for age and sex. Partial $R^{2}$ values showed clusterin FMETVAEK and lubricin LVEVNPK peptide biomarkers explains about 2 to $3 \%$ of the variability of $\triangle J S W$, similar to that explained by age. A biomarker score combining normalized data for both lubricin and clusterin peptides increased the model $R^{2}$ to 0.079 .

Conclusions: Our results suggest that when combined, levels of peptides representative of clusterin and lubricin in plasma are as predictive of OA progression as age. Replication of these findings in other prospective OA cohorts is planned.

\footnotetext{
* Correspondence: aaliprantis@partners.org

'Department of Medicine, Division of Rheumatology, Immunology and Allergy,

Brigham and Women's Hospital, 75 Francis St, Boston, MA 02115, USA

${ }^{2}$ Harvard Medical School, Longwood Ave, Boston, MA 02115, USA

Full list of author information is available at the end of the article
}

\section{Biomed Central}

(c) 2014 Ritter et al.; licensee BioMed Central Ltd. This is an Open Access article distributed under the terms of the Creative Commons Attribution License (http://creativecommons.org/licenses/by/4.0), which permits unrestricted use, distribution, and reproduction in any medium, provided the original work is properly cited. The Creative Commons Public Domain Dedication waiver (http://creativecommons.org/publicdomain/zero/1.0/) applies to the data made available in this article, unless otherwise stated. 


\section{Introduction}

Osteoarthritis (OA) is a common, debilitating disease and knee osteoarthritis is a significant public health problem, estimated to cost up to $\$ 185$ billion per year [1]. Currently, no effective disease-modifying OA drugs are available. The drug development pipeline has been limited by the heterogeneity of OA, the slowly progressive nature of the disease and the fact that there can be long periods of asymptomatic degeneration. Biomarkers that can detect those at risk for disease progression would be beneficial and could minimize the duration and cost of drug discovery [2].

Most biomarkers are proteins and have classically been quantitated with immunoassays. The cost and time needed to develop specific, well-performing antibodies for immunoassays is limiting [3]. Mass spectrometry has emerged as a technology that can measure proteins in routine clinical core laboratories [4] and has the benefit of being able to multiplex analytes and take into account protein variants at the amino acid level [5]. Recent studies have shown mass spectrometry-based assays can have the excellent reproducibility that is necessary for tests in clinical laboratories [6,7].

In a previous study, we used proteomics to identify proteins differentially expressed in OA versus normal synovial fluid [8]. As part of a targeted search strategy for novel OA biomarkers, we developed mass spectrometry assays to measure tryptic peptides representative of several of these proteins, as well as other proteins from previous discovery experiments [9]. These mass spectrometry assays, known as selected reaction monitoring (SRM), use synthetic isotopically labeled peptides for quantitation. We initially developed SRM assays for synovial fluid [8] and subsequently refined them for serum and plasma. The objective of this study was to test a panel of these putative biomarkers in a prospective OA cohort to determine whether peptide concentrations at baseline predict radiographic progression.

\section{Methods}

\section{Study samples}

Synovial fluid and serum samples were collected from participants with full consent and approval under Institutional Review Board (IRB) protocols from Partners Healthcare. The study set consisted of paired synovial fluid and serum samples from 13 patients with late-stage OA taken at the time of joint replacement surgery, and the samples were used to refine our SRM assays.

The progression cohort used for the study was initially described by Mazzuca et al. [10]: 253 subjects were followed for 30 months with serial radiographs and questionnaires. From this cohort, 30\% showed radiographic progression over the study period. From the original cohort, 173 subjects were chosen based on the availability of complete radiographic data and BMI $<35$ to exclude outliers. The plasma used for assays was from the baseline visit. The IRB at Partners Healthcare approved the protocol.

\section{SRM assays}

SRM assays were developed on a TSQ Vantage triple quadrupole mass spectrometer, (Thermo Fisher Scientific, Waltham, MA, USA) as previously described [7,8,11-13]. No depletion of abundant proteins was required. These assays were used to identify potential OA protein biomarkers in paired synovial fluid and serum samples (Table 1).

To obtain quantitative data from the progression cohort, isotopically labeled heavy peptides (AQUA, Thermo Fisher Scientific) were spiked in each sample. Each sample was digested and analyzed two times in the SRM assay in duplicate for a total of four technical replicates. Coefficients of variation (CVs) ranged from 3 to $15 \%$. The average value of these replicates was used in the analyses. Table 2 lists the 19 peptides representative of 9 proteins in plasma used in these assays.

Thermo Scientific Pinpoint SRM Workflow software was used for targeted protein quantification. This software algorithm is used to predict candidate peptides and for choosing multiple fragment ions for SRM assay design, building an instrument method and a sequence file, and also for automatic peptide identity confirmation and quantitative data processing.

\section{Knee imaging}

All patients underwent standardized radiography including semi-flexed anterior-posterior (AP) views of each knee at the baseline and 30-month follow-up study visit [10]. Both knees were analyzed and the knee with the maximal joint loss during the 30-month follow up was used as the index knee to determine the joint space width for analyses.

\section{Statistical analysis}

We used linear regression to determine the association between each peptide biomarker level at baseline and maximal joint space loss $(\mathrm{mm})$ in the index knee from 0 to 30 months, adjusting for age and sex. A second model adjusting for baseline JSW and body mass index (BMI) was also performed. We obtained $R^{2}$ and partial $R^{2}$ values for each model to assess the amount of variance explained by the model $\left(R^{2}\right)$ and the relative contribution of the biomarker (partial $R^{2}$ ). Peptides with a marginal or stronger association $(P<0.2)$ with joint space loss were advanced for further modeling. A biomarker score was developed using a weighted average of peptides showing preliminary evidence of association $(P<0.1$ or odds ratio $(\mathrm{OR})>1.5)$ in the initial analyses. First, the value for each biomarker was standardized by subtracting the mean and dividing by its 
Table 1 Proteins tested by mass spectrometry in matched synovial fluid and serum samples

\begin{tabular}{|c|c|c|c|c|}
\hline Protein & Protein symbol & Peptides, number & Synovial fluid & Serum \\
\hline Aggrecan & ACAN & 14 & Y & $\mathrm{N}$ \\
\hline Cartilage acidic protein 1 & CRTAC1 & 10 & Y & Y \\
\hline Clusterin & CLU & 8 & Y & Y \\
\hline Cartilage oligomeric matrix protein & COMP & 15 & Y & Y \\
\hline Dickkopf 1 homolog & DKK1 & 6 & $\mathrm{~N}$ & $\mathrm{~N}$ \\
\hline Fatty acid binding protein 5 & FABP5 & 2 & Y & Y \\
\hline Follistatin & FST & 11 & $\mathrm{~N}$ & $\mathrm{~N}$ \\
\hline Group XV phospholipase A2 & PLA2G15 & 8 & $\mathrm{~N}$ & N \\
\hline Hepatocyte growth factor & HGF & 1 & Y & Y \\
\hline Hyaluronan and proteoglycan link protein & HAPLN & 13 & $\mathrm{~N}$ & $\mathrm{~N}$ \\
\hline Insulin-like growth factor-binding complex acid labile subunit & IGFALS & 13 & Y & Y \\
\hline Kallistatin & SERPINA4 & 5 & Y & Y \\
\hline Lumican & LUM & 5 & Y & Y \\
\hline Lysosomal phospholipase & ACP2 & 6 & $\mathrm{~N}$ & $\mathrm{~N}$ \\
\hline Matrix metalloproteinase 3 & MMP3 & 10 & Y & Y \\
\hline Pigment epithelium derived factor & PEDF & 12 & Y & Y \\
\hline Procollagen C-endopeptidase enhancer 1 & PCOLCE & 7 & Y & Y \\
\hline Protein S100-A16 & S100A16 & 1 & Y & Y \\
\hline Semenogelin-2 & SEMG2 & 2 & Y & Y \\
\hline Type 1 Collagen (a1, a2) & COL1A & 3 & Y & Y \\
\hline Type 2 Collagen (a1) & COL2A1 & 1 & Y & Y \\
\hline Type 3 Collagen (a1) & COL3A1 & 1 & Y & Y \\
\hline Xaa-Pro dipeptidase & PEPD & 14 & $\mathrm{~N}$ & $\mathrm{~N}$ \\
\hline
\end{tabular}

$\mathrm{Y}$, yes; N, no.

standard deviation. Second, the two standardized scores were added to create a biomarker score from the weighted average, with weights equal to the parameters from linear regression. In this way, differing scales for each biomarker did not influence the results. Linear associations between the individual peptide biomarkers were examined using Pearson correlation. As a secondary analysis we examined the association between each peptide biomarker level at baseline and 30-month change in the Western Ontario and McMaster Universities Arthritis Index (WOMAC). All analyses were performed using SAS.

\section{Results}

Translation of peptide biomarkers from synovial fluid to serum

We initially selected 23 proteins as possible biomarkers (Table 1). These proteins were selected from discovery proteomics experiments comparing $\mathrm{OA}$ and normal synovial fluid $([8,9]$ and data not shown) and lists of previously published OA biomarkers. Multiple peptides generated by tryptic digestion were tested for each of these 23 proteins to refine our assays. Table 1 shows those proteins that were detectible in synovial fluid and/or serum. Peptides representative of six proteins could not be identified in either serum or synovial fluid (lyosomal phospholipase (ACP2), dickkopf 1 (DKK1), follistatin (FST), hyaluronan and proteglycan link protein (HAPLN), group XV phospholipase A2 (PLA2G15), xaaPro dipeptidase (PEPD). Peptides representative of one protein, aggrecan (ACAN) were identified in synovial fluid but could not be identified in serum. Most important, the SRM assays were capable of identifying peptides from 16 proteins in both synovial fluid and serum: cartilage acidic protein 1 (CRTAC1), clusterin (CLU), cartilage oligomeric matrix protein (COMP), fatty acid binding protein 5 (FABP5), hepatocyte growth factor (HGF), insulin-like growth factor-binding complex acid labile subunit (IGFALS), kallistatin (SERPINA4), lumican (LUM), matrix metalloproteinase (MMP3), pigment epithelium-derived factor (PEDF), procollagen C-endopeptidase enhancer 1 (PCOLCE), protein S100-A16 (S100A16), semenogelin (SEMG2), type 1 collagen (COL1A), type 2 collagen (COL2A1), and type 3 collagen (COL3A1). 
Table 2 Peptides and proteins assayed by selected reaction monitoring

\begin{tabular}{ll}
\hline Protein & Peptide sequence \\
\hline Afamin & FLVNLVK \\
Afamin & LPNNVLQEK \\
Clusterin & TLLSNLEEAK \\
Clusterin & FMETVAEK \\
Cartilage oligomeric matrix protein & AVAEPGIQLK \\
Hepatocyte growth factor & ESWVLTAR \\
Insulin-like growth factor-binding protein & LAELPADALGPLQR \\
complex acid labile subunit & \\
Insulin-like growth factor-binding protein & TFTPQPPGLER \\
complex acid labile subunit & \\
Kallistatin & LGFTDLFSK \\
Kallistatin & FFSAQTNR \\
Lubricin & LVEVNPK \\
Lubricin & TFFFK \\
Lubricin & C(-CH ${ }_{2}$-COOH)FESFER \\
Lubricin & GFGGLTGQIVAALSTAK \\
Lumican & ISNIPDEYFK \\
Lumican & FNALQYLR \\
Pigment epithelium-derived factor & ELLDTVTAPQK \\
Pigment epithelium-derived factor & TVQAVLTVPK \\
Pigment epithelium-derived factor & LSYEGEVTK \\
\hline
\end{tabular}

\section{Measurement of peptide biomarkers in an OA} progression cohort

The progression cohort used for this study was a subset of the cohort described by Mazzuca et al. [10]. This cohort was predominantly female and obese. Fifty percent had grade-3 OA of the knee at entry into the study [10]. Our subset of subjects had an average age of 62 years

Table 3 Characteristics of 173 subjects at baseline

\begin{tabular}{ll}
\hline Characteristic & Mean (SD) or number (\%) \\
\hline Age, years & $61.8(9.6)$ \\
Body mass index, $\mathrm{kg} / \mathrm{m}^{2}$ & $30.5(5.1)$ \\
Sex & \\
Female & $134(77 \%)$ \\
Male & $39(23 \%)$ \\
Race & \\
Black & $35(25 \%)$ \\
White & $138(20 \%)$ \\
Years of knee pain & $9.0(9.6)$ \\
Years of osteoarthritis diagnosis & $5.9(6.2)$ \\
WOMAC pain & $4.9(4.1)$ \\
Osteophytes & $143(83 \%)$ \\
Change in joint space width at 30 months & $-0.68(0.64)$ \\
\hline
\end{tabular}

WOMAC, Western Ontario and McMaster Universities Arthritis Index. and average joint space narrowing over 30 months of $0.68 \mathrm{~mm}$ (Table 3). About $83 \%$ of the subjects in this cohort had osteophytes and the WOMAC pain score averaged 4.9.

We selected 19 peptides representative of 9 proteins to test in this cohort. Seven of these proteins were included in the matched synovial fluid/serum study (Table 1). We also included peptides from lubricin, given reports of elevated lubricin expression in the OA joint [14,15], and afamin, which we recently showed to be increased in OA synovial fluid [8]. The proteins and the respective peptides tested in the progression cohort are listed in Table 2. For seven proteins multiple peptides were tested. For ease of identification, when referring to a particular peptide, we use the protein name followed by the first letter of the peptide tested.

All peptides negatively correlated with joint space narrowing, although this correlation did not reach statistical significance. However, peptides for clusterin, lubricin and lumican showed preliminary evidence of association (Table 4). In these models, clusterin(F) and lubricin(L) had the highest $R^{2}$ value and significance. In the adjusted models (Table 4 , even numbered models), the partial $R^{2}$ values of 0.022 for clusterin(F) and 0.033 for lubricin(L) are similar to the partial $R^{2}$ values for age in the models, with significant $P$-values of $<0.05$. Adding baseline JSW and BMI to the models as additional confounders did not change the relationship between the biomarker and $\Delta \mathrm{JSW}$ for any peptide. Neither baseline JSW nor BMI were statistically significantly associated with JSW progression in any of the models evaluated (Additional file 1: Table S1).

As one biomarker may not be sufficient to predict OA progression, we developed a biomarker score using a weighted average of clusterin $(\mathrm{F})$ and lubricin(L). Using this biomarker score further increased our model $R^{2}$ to 0.079 (Table 4, model 13). As a secondary analysis, we looked for correlations between the different peptides for each protein. As expected, peptides that represented the same protein were highly correlated (Table 5, bolded correlations). In contrast, peptides from different proteins had much lower correlations.

We also looked at how our peptides predicted change in the functional WOMAC scale. The mean change in total WOMAC over 30 months was -1.1 (SD 16.8) (scaled 0 to 100 , with 100 being the worst). Pearson correlation coefficients ranged from -0.07 (PEDF(E)) to 0.10 (IGFALS $(\mathrm{L})$ ). None of the peptides met the $P<0.2$ criterion for marginal or stronger association. IGFALS (L) displayed the highest $R^{2}$ value of $0.0095(P=0.2031)$.

\section{Discussion}

The development of clinically meaningful medical therapeutics for OA has not progressed for decades. Unlike, for example, rheumatoid arthritis, in which inflammatory markers and autoantibodies portend worse outcomes, OA 
Table 4 Linear regression models

\begin{tabular}{|c|c|c|c|c|c|}
\hline $\begin{array}{l}\text { Model } \\
\text { number }\end{array}$ & Model $R^{2}$ & Parameter & $\begin{array}{l}\text { Parameter } \\
\text { estimate }\end{array}$ & $\begin{array}{l}\text { Partial } \\
R^{2}\end{array}$ & $P$-value \\
\hline 1 & 0.008 & Clusterin(T) & -1.12 & 0.008 & 0.25 \\
\hline \multirow[t]{3}{*}{2} & 0.061 & Clusterin(T) & -1.85 & 0.020 & 0.06 \\
\hline & & Age & -0.01 & 0.029 & 0.02 \\
\hline & & Sex & 0.24 & 0.023 & 0.05 \\
\hline 3 & 0.008 & Clusterin $(\mathrm{F})$ & -0.92 & 0.008 & 0.25 \\
\hline \multirow[t]{3}{*}{4} & 0.063 & Clusterin(F) & -1.64 & 0.022 & 0.05 \\
\hline & & Age & -0.01 & 0.028 & 0.03 \\
\hline & & Sex & 0.26 & 0.026 & 0.03 \\
\hline 5 & 0.018 & Lubricin(L) & -15.03 & 0.018 & 0.08 \\
\hline \multirow[t]{3}{*}{6} & 0.075 & Lubricin(L) & -20.96 & 0.033 & 0.01 \\
\hline & & Age & -0.01 & 0.030 & 0.02 \\
\hline & & Sex & 0.24 & 0.024 & 0.04 \\
\hline 7 & 0.009 & Lubricin(T) & -7.15 & 0.009 & 0.22 \\
\hline \multirow[t]{3}{*}{8} & 0.059 & Lubricin(T) & -10.43 & 0.018 & 0.07 \\
\hline & & Age & -0.01 & 0.030 & 0.02 \\
\hline & & Sex & 0.21 & 0.019 & 0.07 \\
\hline 9 & 0.011 & Lumican(F) & -4.24 & 0.011 & 0.17 \\
\hline \multirow[t]{3}{*}{10} & 0.047 & Lumican(F) & -3.15 & 0.006 & 0.31 \\
\hline & & Age & -0.01 & 0.018 & 0.07 \\
\hline & & Sex & 0.19 & 0.015 & 0.10 \\
\hline 11 & 0.009 & Lumican(I) & -4.14 & 0.009 & 0.21 \\
\hline \multirow[t]{3}{*}{12} & 0.048 & Lumican(I) & -3.61 & 0.007 & 0.28 \\
\hline & & Age & -0.01 & 0.018 & 0.08 \\
\hline & & Sex & 0.20 & 0.017 & 0.08 \\
\hline \multirow[t]{3}{*}{13} & 0.079 & Biomarker score ${ }^{1}$ & $-0.13^{*}$ & 0.038 & 0.01 \\
\hline & & Age & -0.01 & 0.031 & 0.02 \\
\hline & & Sex & 0.28 & 0.030 & 0.02 \\
\hline
\end{tabular}

${ }^{1}$ Used standardized beta estimates for Clusterin(F) and Lubricin(L) from models 4 and 6 , respectively, to create a weighted sum of the two biomarkers. *One standard deviation of change in biomarker score. lacks biomarkers of disease progression. This, combined with the relatively protracted disease course of OA, has made drug development a major challenge. The ability to predict disease progression with a simple blood test would be a major advance.

Here, we have developed plasma-based, mass spectrometry assays to detect peptides representative of proteins we identified as differentially expressed in OA versus normal synovial fluid [8]. In addition, given its importance in OA pathophysiology [16], similar assays to quantify lubricin peptides in plasma were also developed. The high correlation between different peptides for each protein suggests that our peptide assays are representative of the level of the protein they were designed to measure. Levels of our peptides were correlated with maximal change in joint space over 30 months in a well-characterized OA progression cohort. Previously published risk factors in this cohort include age, WOMAC function, contralateral knee OA, ipsilateral patellofemoral OA and baseline JSW [10]. In our adjusted models, the clusterin $(\mathrm{F})$ and lubricin $(\mathrm{L})$ partial $R^{2}$ values were similar to age. The finding that our biomarker score was as predictive as age, lends validity to our approach. Although the associations were modest and only clusterin(F) and lubricin(L) achieved statistical significance after adjusting for age and sex, the observation that all peptides negatively correlated with maximal change in joint space suggests our approach may be capturing, in peripheral blood, the ongoing pathophysiology within the OA joint. Supporting this line of reasoning is the biologic relevance of the two proteins (clusterin and lubricin) for which the tryptic peptides in plasma best predicted joint space narrowing in a combined biomarker score.

Clusterin, also known as Apolipoprotein J, is a secreted protein that regulates apoptosis and inflammation. A few studies have observed elevated clusterin in cartilage and synovial fluid in early OA $[17,18]$. Conversely, decreased clusterin has been observed in rheumatoid arthritis synovial tissues [19]. Clusterin has multiple functions but is best known as a complement regulatory protein where it binds and inactivates the membrane attack complex (MAC) [20]. Interestingly, complement was recently reported to play a role in the pathogenesis of osteoarthritis

Table 5 Pearson correlation matrix for clusterin, lubricin and lumican peptides

\begin{tabular}{|c|c|c|c|c|c|c|c|}
\hline & Change in joint space width (JSW) & Clusterin(F) & Clusterin $(\mathrm{T})$ & Lubricin(L) & Lubricin(T) & Lumican(F) & Lumican(I) \\
\hline Change in JSW & 1.000 & -0.088 & -0.088 & -0.135 & -0.094 & -0.105 & -0.096 \\
\hline Clusterin(F) & & 1.000 & 0.920 & 0.514 & 0.488 & 0.346 & 0.356 \\
\hline Clusterin( $\mathrm{T})$ & & & 1.000 & 0.423 & 0.429 & 0.401 & 0.382 \\
\hline Lubricin(L) & & & & 1.000 & 0.958 & 0.100 & 0.105 \\
\hline Lubricin(T) & & & & & 1.000 & 0.123 & 0.114 \\
\hline Lumican(F) & & & & & & 1.000 & 0.858 \\
\hline Lumican(I) & & & & & & & 1.000 \\
\hline
\end{tabular}

Values in bold represent strong correlation. 
with mice lacking complement components protected from post-traumatic $\mathrm{OA}$ and a demonstration that sublytic concentrations of MAC could promote a catabolic phenotype in chondrocytes [21]. The higher levels of clusterin in the OA joint [8] and detected in plasma here may represent activation of a compensatory, but ultimately ineffective, protective pathway. Indeed it has been previously reported that glomerular masangial cells upregulate clusterin expression in response to sub-lytic MAC and in in vivo models of glomerular injury [22]. Whether the upregulation of clusterin in OA synovial fluid represents a similar response should be determined.

The other biomarker that performed well in our analyses was tryptic peptide derived from lubricin, also known as proteoglycan 4 and encoded by the PRG4 gene. This protein is found in synovial fluid, the surface of cartilage, tendons and menisci as well as many other tissues. It is a very large water-soluble glycoprotein with a known role as a joint lubricant [23]. It may also have a role in protecting cartilage surfaces and controlling synovial cell growth [24]. Similar to clusterin, lubricin is upregulated in OA synovial fluid and may also represent activation of a response to local joint injury [14]. Interestingly, despite this upregulation, overexpression of lubricin within the joint in mouse models of OA is protective, suggesting the endogenous response in $\mathrm{OA}$ is insufficient [15]. Thus, lubricin is both an attractive biomarker and potential therapy for OA.

Investigations into biomarkers of $\mathrm{OA}$ have been underway for more than 20 years yet none are in clinical practice [25]. Urinary C-terminal telopeptide of collagen type II (uCTX-II) and COMP have been studied for many years as burden of disease and prognostic biomarkers [26-28]. A recent community-based cohort study showed higher COMP predicting incident OA over the next 6 years [28]. Lately, interest in this area has increased with the identification of new candidate biomarkers for progression. More recent additions include the alarmins S100A8/S100A9 [29], showing higher levels in those who progressed over 2 years, adipokines, such as leptin and resistin, which predict progressive and incident OA respectively [30], and TNF-stimulated gene 6 (TSG-6), which predicts radiographic progression over 3 years [31]. Some studies suggest that panels of biomarkers may better predict outcomes and that there is additive value in combining multiple markers [32,33].

This study introduces an approach for protein biomarker development to the OA field, which allows for rapid assay development, SRM mass spectrometry, to identify tryptic peptides representative of target proteins. Mass spectrometry is being increasingly used in clinical laboratories where it has been shown to be simple, robust, precise and less costly than traditional immunoassays $[3,5,34,35]$. Moreover, the ability to multiplex analytes in very small volumes of samples is another strength of this technology. The assays used for this publication required only $25 \mu \mathrm{L}$ of sample yet were able to identify many different peptides. Using freely available peptide information from online repositories [36], peptides can be selected and rapidly tested in SRM assays. If detailed biology is available about post-translational modifications of proteins, this can be incorporated into the design of the assays as well [37].

A strength of this work is the large number of plasma samples analyzed from the progression cohort. Furthermore, the cohort was followed prospectively with standardized radiographs and with our SRM assays we were able to generate quantitative and reproducible data for our target peptides. Our study has important limitations. We performed an index knee analysis, whereby only the knee with the greatest change in JSW was considered. The contralateral knee, which may or may not have had progressive OA, was not taken into account. In addition, our analysis was not powered to predict change in WOMAC and did not incorporate relative differences in the change in joint space in the medial versus the lateral compartments or osteophyte progression, as these data were not available. The variability of our peptides among our samples was limited, restricting our ability to detect changes that might be associated with joint space narrowing. In addition, this cohort already had OA, with a majority having at least grade- 3 radiographic disease. As some of our proteins were selected based on differences in the synovial fluid from subjects with normal and late OA, the advanced disease in our cohort may have made it challenging to detect major associations between these biomarkers and change in joint space. Likewise, few differences were noted in the synovial fluid proteome of knee OA patients with early and late disease $[8,9]$, suggesting the disease process is entrenched by the time symptoms appear. Thus, measurement of our biomarkers in cohorts of patients with preradiographic disease is planned to see if these peptides predict OA progression. A further weakness is that our biomarkers were only measured at the baseline time point. Thus, it is unknown whether these biomarkers change over time, and if this change may be more predictive of OA progression than a baseline measurement. Finally, our data focused on knee OA, so we cannot make any generalizations to other forms of OA based on our data.

\section{Conclusions}

In conclusion, targeted mass spectrometry assays provide a rapid means to measure novel biomarkers in human samples. Our results suggest that when combined, clusterin and lubricin peptide levels in plasma are as predictive of OA progression as age. Replication of these findings in prospective progression and incidence OA cohorts is planned. 


\section{Additional file}

Additional file 1: Table S1. Linear regression models adjusting for age, sex, body mass index (BMI) and baseline joint space width (JSW).

\section{Abbreviations}

ACAN: aggrecan; ACP2: lyosomal phospholipase; BMl: body mass index; CLU: clusterin; COL1A: type 1 collagen; COL2A1: type 2 collagen; COL3A1: type 3 collagen; COMP: cartilage oligomeric matrix protein; CRTAC1: cartilage acidic protein 1; DKK1: dickkopf 1 homolog; FABP5: fatty acid binding protein 5; FST: follistatin; HAPLN: hyaluronan and proteglycan link protein; HGF: hepatocyte growth factor; IGFALS: insulin-like growth factor-binding complex acid labile subunit; IRB: Institutional Review Board; JSW: joint space width; LUM: lumican; MAC: membrane attack complex; MMP: matrix metalloproteinase; OA: osteoarthritis; PCOLCE: procollagen C-endopeptidase enhancer 1; PEDF: pigment epithelium-derived factor; PEPD: xaa-pro dipeptidase; PLA2G15: group XV phospholipase A2; S100A16: protein S100-A16; SEMG: semenogelin; SERPINA4: kallistatin; SRM: selected reaction monitoring; TNF: tumor necrosis factor; UCTX-II: urinary C-terminal telopeptide of collagen type II; WOMAC: Western Ontario and McMaster Universities Arthritis Index; $\triangle$ SW: change in joint space width.

\section{Competing interests}

Dr Aliprantis received consulting fees from Nutech Medical, Inc. The other authors declare that they have no competing interests.

\section{Authors' contributions}

SR and AA conceived of the study, obtained the patient samples, analyzed the data, designed and performed the statistical analysis and drafted the manuscript. JC and EL participated in the design of the study, statistical analysis and helped to draft the manuscript. BK, DS, ML carried out the SRM assays. All authors read and approved the final manuscript.

\section{Acknowledgements}

We thank NIAMS for providing samples from the progression cohort, Alejandra Garces at BRIMS for technical expertise in running the SRM assays, and William Reichman for contributions to the initial statistical design. This work was supported by the following funding sources: NIH K08AR054859 (AOA); Burroughs Wellcome Fund Career Award (AOA); NIH T32 AR007530 (SYR); NIH K24 AR057827 (EL).

\section{Author details}

${ }^{1}$ Department of Medicine, Division of Rheumatology, Immunology and Allergy, Brigham and Women's Hospital, 75 Francis St, Boston, MA 02115, USA. 'Harvard Medical School, Longwood Ave, Boston, MA 02115, USA. ${ }^{3}$ Department of Orthopedic Surgery, Brigham and Women's Hospital, 75 Francis St, Boston, MA 02115, USA. ${ }^{4}$ Thermo Fisher Scientific - BRIMS Center, Cambridge, MA 02139, USA

Received: 22 February 2014 Accepted: 11 September 2014 Published online: 07 October 2014

\section{References}

1. Kotlarz H, Gunnarsson CL, Fang H, Rizzo JA: Insurer and out-of-pocket costs of osteoarthritis in the US: Evidence from national survey data. Arthritis Rheum 2009, 60:3546-3553.

2. Mobasheri A: Osteoarthritis year 2012 in review: biomarkers. Osteoarthritis Cartilage 2012, 20:1451-1464.

3. Hoofnagle AN, Wener MH: The fundamental flaws of immunoassays and potential solutions using tandem mass spectrometry. $J$ Immunol Methods 2009, 347:3-11.

4. Agger SA, Marney LC, Hoofnagle AN: Simultaneous quantification of apolipoprotein A-I and apolipoprotein B by liquid-chromatographymultiple- reaction-monitoring mass spectrometry. Clin Chem 2010, 56:1804-1813.

5. Fu Q, Schoenhoff FS, Savage WJ, Zhang P, Van Eyk JE: Multiplex assays for biomarker research and clinical application: translational science coming of age. Proteomics Clin Appl 2010, 4:271-284.

6. Addona TA, Abbatiello SE, Schilling B, Skates SJ, Mani DR, Bunk DM, Spiegelman $\mathrm{CH}$, Zimmerman $\sqcup$, Ham AJ, Keshishian H, Hall SC, Allen S, Blackman RK,
Borchers CH, Buck C, Cardasis HL, Cusack MP, Dodder NG, Gibson BW, Held JM, Hiltke T, Jackson A, Johansen EB, Kinsinger CR, Li J, Mesri M, Neubert TA, Niles RK, Pulsipher TC, Ransohoff D, et al: Multi-site assessment of the precision and reproducibility of multiple reaction monitoring-based measurements of proteins in plasma. Nat Biotechno/ 2009, 27:633-641.

7. Prakash A, Rezai T, Krastins B, Sarracino D, Athanas M, Russo P, Ross MM, Zhang H, Tian Y, Kulasingam V, Crabovich AP, Smith C, Batruch I, Liotta L, Petricoin E, Diamandis EP, Chand DW, Lopez MF: Platform for establishing interlaboratory reproducibility of selected reaction monitoring-based mass spectrometry peptide assays. J Proteome Res 2010, 9:6678-6688.

8. Ritter SY, Subbaiah R, Bebek G, Crish J, Scanzello CR, Krastins B, Sarracino D, Lopez MF, Crow MK, Aigner T, Goldring MB, Goldring SR, Lee DM, Gobezie R, Aliprantis AO: Proteomic analysis of synovial fluid from the osteoarthritic knee: comparison with transcriptome analyses of joint tissues. Arthritis Rheum 2013, 65:981-992.

9. Gobezie R, Kho A, Krastins B, Sarracino DA, Thornhill TS, Chase M, Millett PJ, Lee DM: High abundance synovial fluid proteome: distinct profiles in health and osteoarthritis. Arthritis Res Ther 2007, 9:R36.

10. Mazzuca SA, Brandt KD, Katz BP, Ding Y, Lane KA, Buckwalter KA: Risk factors for progression of tibiofemoral osteoarthritis: an analysis based on fluoroscopically standardised knee radiography. Ann Rheum Dis 2006, 65:515-519.

11. Campbell J, Rezai T, Prakash A, Krastins B, Dayon L, Ward M, Robinson S, Lopez M: Evaluation of absolute peptide quantitation strategies using selected reaction monitoring. Proteomics 2011, 11:1148-1152.

12. Lopez MF, Kuppusamy R, Sarracino DA, Prakash A, Athanas M, Krastins B, Rezai T, Sutton JN, Peterman S, Nicolaides K: Mass spectrometric discovery and selective reaction monitoring (SRM) of putative protein biomarker candidates in first trimester Trisomy 21 maternal serum. J Proteome Res 2011, 10:133-142.

13. Lopez MF, Sarracino DA, Prakash A, Athanas M, Krastins B, Rezai T, Sutton JN, Peterman S, Gvozdyak O, Chou S, Lo E, Buonanno F, Ning M: Discrimination of ischemic and hemorrhagic strokes using a multiplexed, mass spec-based assay for serum apolipoproteins coupled to multimarker ROC algorithm. Proteomics Clin Appl 2012, 6:190-200.

14. Neu CP, Reddi AH, Komvopoulos K, Schmid TM, Di Cesare PE: Increased friction coefficient and superficial zone protein expression in patients with advanced osteoarthritis. Arthritis Rheum 2010, 62:2680-2687.

15. Ruan MZ, Erez A, Guse K, Dawson B, Bertin T, Chen Y, Jiang MM, Yustein J, Gannon F, Lee BH: Proteoglycan 4 expression protects against the development of osteoarthritis. Sci Trans/ Med 2013, 5:176ra134.

16. Waller KA, Zhang LX, Elsaid KA, Fleming BC, Warman ML, Jay GD: Role of lubricin and boundary lubrication in the prevention of chondrocyte apoptosis. Proc Natl Acad Sci USA 2013, 110:5852-5857.

17. Connor JR, Kumar S, Sathe G, Mooney J, O'Brien SP, Mui P, Murdock PR, Gowen M, Lark MW: Clusterin expression in adult human normal and osteoarthritic articular cartilage. Osteoarthritis Cartilage 2001, 9:727-737.

18. Fandridis E, Apergis G, Korres DS, Nikolopoulos K, Zoubos AB, Papassideri I, Trougakos IP: Increased expression levels of apolipoprotein J/clusterin during primary osteoarthritis. In Vivo 2011, 25:745-749.

19. Devauchelle V, Essabbani A, De Pinieux G, Germain S, Tourneur L, Mistou S, Margottin-Goguet F, Anract P, Migaud H, Le Nen D, Lequerre T, Saraux A Dougados M, Breban M, Rournier C, Chiocchia G: Characterization and functional consequences of underexpression of clusterin in rheumatoid arthritis. J Immunol 2006, 177:6471-6479.

20. Tschopp J, French LE: Clusterin: modulation of complement function. Clin Exp Immunol 1994, 97:11-14.

21. Wang Q, Rozelle AL, Lepus CM, Scanzello CR, Song JJ, Larsen DM, Crish JF, Bebek G, Ritter SY, Lindstrom TM, Hwang I, Wong HH, Punzi L, Encarnacion A, Shamloo M, Goodman SB, Wyss-Coray T, Goldring SR, Banda NK, Thurman JM, Gobezie R, Crow MK, Holers VM, Lee DM, Robinson WH: Identification of a central role for complement in osteoarthritis. Nat Med 2011, 17:1674-1679.

22. Yamada K, Hori Y, Hanafusa N, Okuda T, Nagano N, Choi-Miura NH, Couser WG, Miyata T, Kurokawa K, Fujita T, Nangaku M: Clusterin is up-regulated in glomerular mesangial cells in complement-mediated injury. Kidney Int 2001, 59:137-146.

23. Jay $G D$, Britt $D E$, Cha $C$ : Lubricin is a product of megakaryocyte stimulating factor gene expression by human synovial fibroblasts. J Rheumatol 2000, 27:594-600.

24. Rhee DK, Marcelino J, Baker M, Gong Y, Smits P, Lefebvre V, Jay GD, Stewart M, Wang H, Warman ML, Carpten JD: The secreted glycoprotein lubricin protects 
cartilage surfaces and inhibits synovial cell overgrowth. J Clin Invest 2005, 115:622-631.

25. Brandt KD: A pessimistic view of serologic markers for diagnosis and management of osteoarthritis. Biochemical, immunologic and clinicopathologic barriers. J Rheumatol Suppl 1989, 18:39-42.

26. Dam EB, Byrjalsen I, Karsdal MA, Qvist P, Christiansen C: Increased urinary excretion of C-telopeptides of type II collagen (CTX-II) predicts cartilage loss over 21 months by MRI. Osteoarthritis Cartilage 2009, 17:384-389.

27. Kraus VB, Kepler TB, Stabler T, Renner J, Jordan J: First qualification study of serum biomarkers as indicators of total body burden of osteoarthritis. PLoS One 2010, 5:e9739.

28. Golightly YM, Marshall SW, Kraus VB, Renner JB, Villaveces A, Casteel C, Jordan JM: Biomarkers of incident radiographic knee osteoarthritis: Do they vary by chronic knee symptoms? Arthritis Rheum 2011, 63:2276-2283.

29. van Lent PL, Blom AB, Schelbergen RF, Sloetjes A, Lafeber FP, Lems WF, Cats H, Vogl T, Roth J, van den Berg WB: Active involvement of alarmins S100A8 and S100A9 in the regulation of synovial activation and joint destruction during mouse and human osteoarthritis. Arthritis Rheum 2012, 64:1466-1476.

30. de Boer TN, van Spil WE, Huisman AM, Polak AA, Bijlsma JW, Lafeber FP, Mastbergen SC: Serum adipokines in osteoarthritis; comparison with controls and relationship with local parameters of synovial inflammation and cartilage damage. Osteoarthritis Cartilage 2012, 20:846-853.

31. Wisniewski HG, Colon E, Liublinska V, Karia RJ, Stabler TV, Attur M, Abramson SB, Band PA, Kraus VB: TSG-6 activity as a novel biomarker of progression in knee osteoarthritis. Osteoarthritis Cartilage 2014, 22:235-241.

32. Ishijima M, Watari T, Naito K, Kaneko H, Futami I, Yoshimura-Ishida K, Tomonaga A, Yamaguchi H, Yamamoto T, Nagaoka I, Kurosawa H, Poole RA, Kaneko K: Relationships between biomarkers of cartilage, bone, synovial metabolism and knee pain provide insights into the origins of pain in early knee osteoarthritis. Arthritis Res Ther 2011, 13:R22.

33. van Spil WE, Jansen NW, Bijlsma JW, Reijman M, DeGroot J, Welsing PM, Lafeber FP: Clusters within a wide spectrum of biochemical markers for osteoarthritis: data from CHECK, a large cohort of individuals with very early symptomatic osteoarthritis. Osteoarthritis Cartilage 2012, 20:745-754.

34. Krastins B, Prakash A, Sarracino DA, Nedelkov D, Niederkofler EE, Kiernan UA, Nelson R, Vogelsang MS, Vadali G, Garces A, Sutton JN, Peterman S, Byram G, Darbouret B, Perusse JR, Seidah NG, Coulombe B, Gobom J, Portlius E, Panne J, Blennow K, Kulaqsingam V, Couchman L, Moniz C, Lopez MF: Rapid development of sensitive, high-throughput, quantitative and highly selective mass spectrometric targeted immunoassays for clinically important proteins in human plasma and serum. Clin Biochem 2013, 46:399-410.

35. Hoofnagle AN, Becker JO, Oda MN, Cavigiolio G, Mayer P, Vaisar T: Multiple-reaction monitoring-mass spectrometric assays can accurately measure the relative protein abundance in complex mixtures. Clin Chem 2012, 58:777-781.

36. Desiere F, Deutsch EW, King NL, Nesvizhskii Al, Mallick P, Eng J, Chen S, Eddes J, Loevenich SN, Aebersold R: The PeptideAtlas project. Nucleic Acids Res 2006, 34:D655-D658.

37. Bystrom C, Sheng S, Zhang K, Caulfield M, Clarke NJ, Reitz R: Clinical utility of insulin-like growth factor 1 and 2; determination by high resolution mass spectrometry. PLoS One 2012, 7:e43457.

doi:10.1186/s13075-014-0456-6

Cite this article as: Ritter et al:: Mass spectrometry assays of plasma biomarkers to predict radiographic progression of knee osteoarthritis. Arthritis Research \& Therapy 2014 16:456.

\section{Submit your next manuscript to BioMed Central and take full advantage of:}

- Convenient online submission

- Thorough peer review

- No space constraints or color figure charges

- Immediate publication on acceptance

- Inclusion in PubMed, CAS, Scopus and Google Scholar

- Research which is freely available for redistribution

Submit your manuscript at www.biomedcentral.com/submit
Ciomed Central 